\title{
„Dziewięćdziesiąt dziewięć cudzych pomysłów, i ieden autora”. Porównanie myśli konstytucyjnej Wincentego Niemojowskiego i Benjamina Constanta
}

Jeżeli przystępujemy do porównania dzieła Benjamina Constanta Refléxions sur les constitutions et les garanties ${ }^{1}$, z przekładem dokonanym przez lidera opozycji kaliskiej Wincentego Niemojowskiego, to nie tylko po to, aby zarejestrować różnice w poglądach autorów. O monarchii konstytucyyney stanowi wspaniały przykład próby recepcji zachodniej myśli konstytucyjnej do naszych warunków. Zadanie to nie było łatwe, albowiem jak zauważył Monteskiusz: „rzadki to traf, aby prawa jednego narodu mogły się nadać drugiemu”2. Wincenty Niemojowski, który zajął się tłumaczeniem, nie był osobą przypadkową - to czołowy polityk okresu Królestwa Polskiego, solidnie wykształcony na uniwersytetach w Niemczech i Francji, wreszcie, wielki erudyta oraz znawca zagadnień ustrojowych i prawnych. Podjęta przez niego próba przeszczepienia obcej doktryny na grunt Polski była pomysłem oryginalnym. Nie ze względu na Benjamina Constanta, którego ceniono w całej Europie ${ }^{3}$, ale dlatego że mieszkańcy Królestwa Kongresowego, a wcześniej Rzeczypospolitej Obojga Narodów, byli raczej oporni w adaptowaniu trendów intelektualnych pochodzących z innych krajów. Szlachta, dumna z wypracowanej praktyki, na obce pomysły patrzyła zazwyczaj nieufnie.

Przedmiotem pracy jest analiza dzieła $O$ monarchii konstytucyyney i rekoymiach publicznych. Rzecz wzięta z dziet Benjamina Constant przekładnia Win-

${ }^{1}$ B. Constant, Refléxions sur les constitutions et les garanties publiées le 24 mai 1814, avec une esquisse de constitution, [w:] idem, Collection complčte des ouvrages publiés sur le Gouvernement représentatif et la Constitution actuelle de la France, formant une espèce de Cours de Politique constitutionnelle, t. I, Paris 1818. Zagadnienie, z której pracy Benjamina Constanta korzystał thumacz, budziło wiele kontrowersji. Na podstawie mojej analizy mogę stwierdzić, że Niemojowski z całą pewnością korzystał z powyższego zbioru.

2 C. Montesquieu, O duchu praw, przeł. Tadeusz Boy-Żeleński, Warszawa 1957, t. I, s. 32.

${ }^{3}$ H. Izdebski, Instytucje przedstawicielskie w myśli politycznej Księstwa Warszawskiego i Królestwa Polskiego (do 1831 roku), [w:] Polska myśl liberalno-demokratyczna w latach 1795-1830, Warszawa 1986, s. 38. 
centego Niemojowskiego ${ }^{4}$. Konstanty Grzybowski w roku 1952 jako pierwszy pisał o potrzebie prześledzenia, jak przywódca opozycji kaliskiej próbował dopasować idee Constanta do potrzeb Polski, a także co i w jaki sposób przekształci15. Wiele lat później podobny postulat badawczy wysunął Bogusław Leśnodorski.

Tytuł rozprawy może być nieco mylący. Obiektem moich badań jest osoba Wincenty Niemojowskiego i jego poglądy, natomiast Benjamin Constant stanowi dla mnie tylko punkt odniesienia. Mimo że idee francuskiego męża stanu stanowią znaczną część pracy, to zostały napisane z myślą o ich thumaczu.

W niniejszych rozważaniach założyłem, że w $O$ monarchii - jeżeli tłumacz tego nie zaznacza - nie ma żadnego merytorycznego zdania niepochodzącego z prac Benjamina Constanta. Porównywałem więc oryginał z thumaczeniem, odnajdując odpowiedni akapit w tekście francuskim. Niniejsza praca w żadnym razie nie ma ambicji filologicznych, tak więc nie zagłębiałem się w deliberacje na temat obcojęzycznych słów albo fraz. Interesuje mnie jedynie treść merytoryczna tekstów.

Mimo bogatej literatury dotyczącej Niemojowskich i opozycji liberalnej w Królestwie Polskim, nie ma bodaj jednego pełnego opracowania zajmującego się $O$ monarchii konstytucyyney. Większość dotychczasowych prac przyjmowała, że stanowi ona po prostu bezkrytyczny przekład dzieła Constanta.

Praca Heleny Więckowskiej Opozycja liberalna w Królestwie Polskim z roku 1925 stanowi do dzisiaj najważniejsze opracowanie dla badań nad Wincentym Niemojowskim i dziejami benjaministów. Zagadnienia związane $z$ opozycją liberalną na tle epoki obejmuje praca Władysława Bortnowskiego ${ }^{6}$ - niestety pozbawiona jest ona zarówno przypisów jak i bibliografii.

Pojawiło się wiele monografii na temat polskiego liberalizmu w XIX wieku. Przede wszystkim wypada wymienić prace: Wilhelma Feldmana, Marcina Janowskiego, Ryszarda Retta Ludwikowskiego, Włodzimierza Bernackiego oraz wstęp do zbioru tekstów Barbary i Marka Sobolewskich ${ }^{7}$. Na uwagę

4 B. Constant, O monarchii konstytucyyney i rekoymiach publicznych. Rzecz wzięta z dziet Benjamina Constant przektadnia Wincentego Niemojowskiego, Warszawa 1831, cz. I, s. 26. W całej pracy będę posługiwał się skrótem $O$ monarchii.... Pierwsza część dzieła jest dostępna w formie elektronicznej, na serwerach Google Books.

5 K. Grzybowski, Dwa nurty polskiej myśli konstytucyjnej, „Kwartalnik Historyczny” LIX, 1952, s. 51; idem, Dwa nurty polskiej myśli konstytucyjnej, [w:] idem, Refleksje sceptyczne, Warszawa 1972 , t. II, s. 215.

${ }^{6}$ W. Bortnowski, Kaliszanie. Kartki z dziejów Królestwa Polskiego, Warszawa 1976.

${ }^{7}$ W. Feldman, Dzieje polskiej myśli politycznej w okresie porozbiorowym, t. I, Warszawa 1988; M. Janowski, Polska myśl liberalna do roku 1918, Kraków 1998, s. 45-84; R.R. Ludwikowski, 
zasługują rozważania Marcelego Handelsmana, który podkreślał bliskie związki polskich liberałów z myślą francuską ${ }^{8}$.

W większości prace polityczne Benjamina Constanta nie doczekały się swoich thumaczeń na język polski ${ }^{9}$. Chlubny wyjątek stanowi $O$ monarchii konstytucyyney. W latach siedemdziesiątych pojawiła się antologia Barbary i Marka Sobolewskich ${ }^{10}$. Ostatnio zostało opublikowane thumaczenie De la religion, considérée dans sa source, ses formes et ses développements ${ }^{11}$, a także przekład fragmentów Principes de politique applicables à tous les gouvernements représentatifs, pochodzących z lat 1806-181012. Przetłumaczona na język polski została też rozprawa Constanta $O$ wolności starożytnych i nowożytnych ${ }^{13}$.

Istnieje tylko jedna polskojęzyczna monografia zajmująca się myślą polityczną Benjamina Constanta, której autorem jest Wacław Szyszkowski ${ }^{14}$. Praca została napisana w sposób bardzo kompletny i śmiało może stanowić wzór dla rozpraw z dziedziny doktryn politycznych. Francuski autor wszedł na stałe do kanonu podręczników akademickich nauczających myśli politycznej i prawnej $^{15}$. Istnieją też artykuły: Michała Bożka, dotyczący władzy neutralnej w koncepcji ustrojowej Constanta ${ }^{16}$, oraz Adama Bosiackiego ${ }^{17}$, traktujący o władzy municypalnej. Nie można zapomnieć o pracy opisującej liberalizm

Glówne nurty myśli liberalnej 1815-1890, Warszawa 1982, s. 194-215; W. Bernacki, Liberalizm polski 1815-1939: studium doktryny politycznej, Kraków 2004, s. 102-120; B. i M. Sobolewscy, Myśl polityczna XIX i XX wieku. Liberalizm, Warszawa 1978, s. 72-78; Z. Rau, Liberalizm: Zarys myśli politycznej XIX i XX wieku, Warszawa 2000, s. 32-42.

8 M. Handelsman, Francja-Polska 1795-1845: studia nad dziejami myśli politycznej. Rozwoj narodowości nowoczesnej, t. II, Warszawa 1926, s. 64-85; idem, Les idees francaises et la mentalite politique en Pologne au XIXe siecle, Paris 1927, s. 27-62.

9 W okresie międzywojennym pojawiło się tłumaczenie T. Boya-Żeleńskiego dzieł literackich Constanta: Adolfa i Czerwonego Kajetu. Bardzo interesujące są też Dzienniki Poufne Benjamina Constanta, przełożone przez Joannę Guze i wydane w Warszawie w roku 1980.

${ }^{10}$ B. i M. Sobolewscy, Myśl polityczna XIX i XX wieku. Liberalizm, Warszawa 1978.

11 B. Constant, O religii, tł. i oprac. S. Kruszyńska, Warszawa 2007; S. Kruszyńska, Benjamin Constant. Filozof religii: religia-moralność-wolność, Gdańsk 2000. Na uwagę zasługuje rozdział wstępny dotyczący życia i działalności Constanta.

12 B. Constant, Zasady polityki majace zastosowanie do wszystkich rzqdów (wersja z lat 1806-1810), tt. A. Dwulit, Warszawa 2008.

13 B. Constant, O wolności starożytnych i nowożytnych, przeł. Z. Kosno, „Arka”, 1992, nr 42, s. $73-84$.

14 W. Szyszkowski, Benjamin Constant. Doktryna polityczno-prawna na tle epoki, Warszawa-Poznań-Toruń 1984.

15 K. Chojnicka, H. Olszewski, Historia doktryn politycznych i prawnych, Poznań 2004, s. 224-228; L. Dubel, Historia doktryn politycznych i prawnych do końca XIX wieku, Warszawa 2002, s. 362-376; H. Izdebski, Historia myśli politycznej i prawnej, Warszawa 2007, s. 366-370.

${ }^{16}$ M. Bożek, Władza neutralna w koncepcji Benjamina Constanta, [w:] Idee jako źródto instytucji politycznych i prawnych, pod red. L. Dubla, Lublin 2003, s. 405-425.

17 A. Bosiacki, Władza municypalna w ujęciu Benjamina Constanta a teorie podziału władzy, „Studia Iuridica” IIL, 2008, s. 341-347. 
we Francji w pierwszej połowie XIX wieku, autorstwa Barbary Sobolewskiej $^{18}$.

Nim przejdę do omawiania treści $O$ monarchii konstytucyyney, potrzebne jest przybliżenie biografii Wincentego Niemojowskiego. Badanie doktryny byłoby niepełne bez chociaż pobieżnego osadzenia jej autora $\mathrm{w}$ ramach historycznych.

„Rodzina Niemojowskich od bardzo dawnych czasów osiadła była w Wielkopolsce” ${ }^{19}$. W czerwcu 1831 roku w gazecie „Nowa Polska” napisano:

„Kaliskie województwo rozpoczęło opozycję, jest ono najliberalniejsze, bowiem kaliskie województwo pod względem uprawy gruntów, przemysłu, zamożności jest prawie pierwsze, celujące. Bliżej jest Prus, bliżej Zachodu, bliżej słońca dającego życie Europie" ${ }^{20}$.

Wincenty Niemojowski urodził się w roku 1784. W wieku szesnastu lat wyjechał na studia prawnicze do Niemiec (Halle, Erlangen i Frankfurt/O). Natomiast ostatni etap swojej edukacji odbył we Francji. Na scenę polityczna, wkroczył w roku 1818, gdy został ,zaszczycony ufnością"21, a co za tym idzie i wyborem na posła powiatu kaliskiego. Tak jego poczynania podczas obrad opisywał niechętny mu Kajetan Koźmian²2:

„Głuchy z trąbką blaszaną u ucha, postawy niekształtnej, ułomny, a śmiały aż do zbytku, tem był trudniejszy do zwalczenia, że mu głuchota przeszkadzała słyszeć dokładnie obrony i przekonania się. Upór więc jego, jak pod tarczą Achillesa, chodził w tej głuchocie" ${ }^{23}$.

18 B. Sobolewska, Doktryna polityczna liberalizmu arystokratycznego we Francji $w$ latach 1815-1848, Kraków 1977, s. 51-210.

19 J.N. Niemojowski, Wspomnienia, Warszawa 1925, s. 4.

${ }^{20}$ Zob. W. Zajewski, Kaliszanie, [w:] Tradycje liberalne w Polsce, s. 86. Autor zwraca uwagę, że jest to pierwszy przykład opinii, iż poglądy liberalne nie rodzą się w pustce ekonomicznej i społecznej; H. Izdebski, Ustawa konstytucyjna Królestwa Polskiego 1815, [w:] Konstytucje Polskie, pod red. M. Kallasa, Warszawa 1990, s. 218.

${ }^{21}$ W. Niemojowski, Głos posła kaliskiego na seym Królestwa Polskiego 1818, Poznań 1818, s. 3.

${ }^{22}$ K. Koźmian w swoich poglądach wyrażał doktrynę podziału władz Benjamina Constanta, ale z silniejszą pozycją ustrojową monarchy. „Władza Najwyższa” miała być pierwszym stróżem porządku konstytucyjnego. Po roku 1820 Koźmian, rozczarowany funkcjonowaniem Konstytucji z 1815 r., zmienił swoje poglądy na mniej liberalne. Zob.: H. Izdebski, Instytucje przedstawicielskie w myśli politycznej Księstwa Warszawskiego i Królestwa Polskiego, s. 35; M. Mycielski, „,Miasto mieszkańców, wieś obywateli". Kajetana Koźmiana koncepcja wspólnoty politycznej (do 1830 roku), Wrocław 2004.

23 Cyt. za: A. Kraushar, Kaliszanie. Niemojowski. Kartki archiwalne z lat 1820-1830, s. 90; W. Zajewski, Niemojowski Wincenty, w: Polski stownik biograficzny XXIII, 1978, s. 31. 
Podczas sesji sejmu 1818 roku poseł kaliski dał się poznać, może ze względu na swoje prawnicze wykształcenie, jako formalista i skrupulant. W oczach współczesnych był postrzegany jako człowiek nieugięty - przede wszystkim jako obrońca praw konstytucyjnych.

Na sejmie w 1820 roku chciał Niemojowski przeprowadzić dwie inicjatywy. Po pierwsze, postulował zniesienie cenzury pism sejmowych. Po wtóre, zamierzał przeforsować nowy regulamin obrad izby poselskiej. Protestował również przeciwko projektowi Statutu organicznego, który miał pozbawiać posłów możliwości pociagnnięcia ministrów do odpowiedzialności przed sądem sejmowym $\mathrm{w}$ przypadku kontrasygnowania przez nich postanowień sprzecznych z konstytucją.

W maju 1825 roku Niemojowski w drodze na obrady Sejmu został zatrzymany na rogatkach Warszawy i pod eskortą Kozaków odwieziony do swojego domu w Przystani. Miał tam spędzić „resztę dni konstytucyjnego Królestwa, gdzie dopiero 29-y rozkuł jego chlubne więzy”. Czas przymusowej izolacji lider opozycji kaliskiej wykorzystał do napisania O monarchii konstytucyyney ${ }^{24}$.

Ani bracia Niemojowscy, ani związani z nimi przedstawiciele sejmowej opozycji nie brali udziału w przygotowaniach do powstania ${ }^{25}$. Jeszcze na początku grudnia Niemojowski objął funkcję redaktora „Kuriera Polskiego"26. 29 stycznia 1831 roku były poseł wieluński wszedł w skład powołanego przez Sejm Rządu Narodowego. W ostatnich dniach powstania był jednym z nielicznych, którzy usiłowali ratować powstanie. Wystarczy powiedzieć, że obrady Rządu toczyły się w jego mieszkaniu. Po upadku Warszawy, dnia 23 września został schwytany przez oddział Czerkiesów przy próbie przekroczenia granicy pruskiej. Wyrokiem Najwyższego Sądu Kryminalnego w 1832 roku został skazany na karę śmierci przez ucięcie głowy. Umarł w drodze na Sybir w grudniu 1834 roku. Najlepszym podsumowaniem działalności politycznej Niemojowskiego niech będą słowa Mochnackiego: „Chciał on tylko kartą konstytucyjną nadwiślańskiej Polski pokryć całą ziemię naszę. Tego nauczał w dobrej wierze”27.

$$
\text { *** }
$$

Teraz kilka słów krytyki $O$ monarchii konstytucyyney i rekoymiach publicznych. Tłumaczenie zostało zaczerpnięte z drugiego wydania Refléxions sur les constitutions, la distribution des pouvoirs, et les garanties, dans une monarchie constitutionnelle ${ }^{28}$, które Benjamin Constant wydał pod tytułem

${ }^{24}$ O monarchii..., Ostrzeżenie.

${ }^{25}$ W. Bortnowski, Kaliszanie: Udziat ,, kaliszan” we wtadzy powstania listopadowego, s. 230.

${ }^{26} \mathrm{Na}$ temat przejęcia gazety przez opozycję liberalną zob. ibidem, s. 232-234.

27 M. Mochnacki, Powstanie narodu polskiej w roku 1830 i 1831, s. 249.

28 B. Constant, Réflexions sur les constitutions, la distribution des pouvoirs, et les garanties, dans une monarchie constitutionnelle, Paris 1814. 
Refléxions sur les constitutions et les garanties ${ }^{29}$ - w pierwszym tomie kompilacji własnych prac politycznych publikowanych od roku 1818 . W porównaniu do pierwszej edycji autor rozszerzył przypisy o doświadczenia związane z wczesnymi latami Restauracji monarchii Burbonów. W pierwszym tomie kompilacji znajduje się wiele odesłań do jego notatek, które można odnaleźć na końcu książki. Dodatkowo wydanie zawiera jeszcze jedną rozprawę: De la liberté des brochures, des pamphlets et des journaux. Niemojowski wykorzystał wszystkie niniejsze prace i uwagi. Teksty Constanta niepochodzące $\mathrm{z}$ tego zbioru to: De la responsabilite des ministres, $\mathrm{z} 1817 \mathrm{roku}^{30}$, a także rozdział XI Principes de Politique - De la responsabilité des agents inférieurs ${ }^{31}$. Notatki i przypisy Constanta zostały scalone z tekstem, przez co można czasem odnieść wrażenie, że thumacz przytacza fragmenty niepochodzące z pracy Constanta. Zdarza się, że kaliski polityk niweluje odstęp między kolejnymi akapitami. W głównej mierze usunięte zostały przykłady odnoszące się bezpośrednio do Francji, jak tłumaczył Niemojowski, aby dzieło miało wydźwięk bardziej uniwersalny ${ }^{32}$.

Całkowicie pomijane w historiografii jest to, że omawiane dzieło niewątpliwie jest niekompletne. Niemojowski wielokrotnie podkreślał, że w drugim wydaniu $O$ monarchii konstytucyyney miał zamiar dokonać wielu uzupełnień. W pracy ostatecznie znalazły się trzy obszerne przypisy tłumacza: o sądzie przysięgłych, jawności obrad oraz wolności druku, a także kilka drobnych uwag.

Tłumacz w przedmowie $O$ monarchii pisze, że przekładu dokonał w czasie swojego uwięzienia - czyli w latach $1825-1830$. Z pierwszym woluminem Collection complète des ouvrages publiés zapoznał się najpóźniej w roku 1820. Wtedy w „Pamiętniku Warszawskim” opublikował pierwszy rozdział nowej edycji Refleksji - o podziale władz konstytucyjnych ${ }^{33}$. Zestawienie obu przekładów może wzbudzić konsternację. O ile treść merytoryczna w obu tłumaczeniach ma jednakowy wydźwięk, to język przekładu jest różny ${ }^{34}$.

${ }^{29}$ Idem, Réflexions sur les constitutions et les garanties publiées le 24 mai 1814, avec une esquisse de constitution, [w:] idem, Collection complete des ouvrages publies sur le Gouvernement representatif et la Constitution actuelle de la France, formant une espece de Cours de Politique constitutionnelle, t. I, Paris 1818; O monarchii..., cz. I, s. 25. Autor informuje, że korzysta z późniejszych wzbogaconych wydań Refleksji nad konstytucjami.

30 B. Constant, Cours de politique constitutionelle, Paris 1861, s. 381-441.

31 Idem, s. 90-97.

32 O monarchii..., cz. I, s. 25.

${ }^{33}$ W. Niemojowski, O Władzach publicznych. W Monarchii Konstytucyyney wedtug B. C. przez W. N., „Pamiętnik Warszawski”, XXI, 1821, s. 386-416.

${ }^{34}$ Zob. też: $O$ monarchii..., cz. I, s. 58 i n. Przytoczę po jednym fragmencie z obu tekstów. W „Pamiętniku Warszawskim”, s. 386-387, Niemojowski tłumaczył: „Zadziwi może nie iednego rozróżnienie władzy Królewskiey od wykonawczey. Ta różnica, długo nieznana, iest iednakże potrzebna, iest może kluczem całey organizacyi polityczney". Natomiast w $O$ monarchii..., s. 58, thumaczenie brzmiało: „Zadziwi to może, iż rozróżniam władzę królewską od wykonawczey. Ta różnica, długo nieznana, iest bardzo potrzebna, iest może kluczem całey organizacyi polityczney". 
Nie wiadomo kiedy dokładnie nastąpiła publikacja pierwszej części $O$ monarchii. Ostrzeżenie oznaczono na dzień 21 grudnia 1830 roku $^{35}$. Prawdopodobnie jeszcze w grudniu I część została oddana do druku. 5 stycznia w „Kurierze Polskim" pojawiła się następująca nota:

„W tych dniach wzięto pod prasę, ważne nader dzieło Benjamina Constanta $O$ monarchji konstytucyjnej przetłumaczone i ułożone przez byłego posła Wincen. Niemojowskiego. Dzieło to w dzisiejszych okolicznościach bardzo będzie użyteczne" ${ }^{\prime 36}$.

Tak więc pierwszy tom pojawił się w sprzedaży w styczniu 1831 roku $^{37}$. Pośpieszne wydanie pierwszego tomu mogło być związane ze wznowieniem obrad sejmowych, wyznaczonych na dzień 17 stycznia. Natomiast na pierwszej karcie drugiej części $O$ monarchii konstytucyyney znajduje się wzmianka, że tłumaczenie było drukowane w ,pamiętnych miesiącach lutym i marcu 1831 r.”, w drukarni A. Gałęzowskiego i spółki w Warszawie.

Wbrew temu, co pisała Helena Więckowska, powstanie listopadowe nie wpłynęło na kształt dzieła ${ }^{38}$. Podstawową przyczyną był fakt, że Niemojowski nie mógł przewidzieć wybuchu „rewolucji”. Trzeba też zwrócić uwagę, że doktryna Constanta nie miała charakteru przewrotowego. Porady francuskiego autora odnoszą się do czasów pokoju, kładą nacisk na powolne zmiany, nie informują, jak konstruować ustrój w czasach rewolucji.

Dlaczego autor postanowił przetłumaczyć całe dzieło Constanta, zamiast dokonać tylko skróconego wyciagu albo nawet opublikowania własnej pracy w duchu doktryny francuskiego męża stanu? „Pewien uczony rodak nazwał tłumaczenie rozważnym czytaniem, gdyż przez to najlepiej poznajemy szkielet myśli’"39. Importowanie tekstów zagranicznych miało poszerzać horyzonty, wzbogacać kulturę o najdoskonalsze pomysły powstałe za granicą a w końcu dać szansę dotrzymania kroku postępowi cywilizacyjnemu w Europie. Przekazywanie prądów intelektualnych pod egidą wielkiego autorytetu, jakim był Constant, miało na celu zwiększenie prestiżu przekazywanych poglądów.

Nasuwa się pytanie, czy Wincenty Niemojowski nie dokonał manipulacji w celu dopasowania tekstu do ówczesnej sytuacji politycznej? Na pierwszy rzut

${ }^{35}$ W. Bortnowski, Kaliszanie: Udzial , kaliszan” we władzy powstania listopadowego, s. 235-236. Tego dnia miało nastapić rozpoczęcie obrad sejmowych.

36 „Kurier Polski” nr 616 z dnia 5 stycznia 1831 r.

37 W. Bortnowski, Walka o cele powstania listopadowego (od 29 listopada 1830 r. do lutego 1831 r.), Wrocław 1960; idem, Kaliszanie: Udziat „,kaliszan” we władzy powstania listopadowego, s. 238 .

${ }^{38}$ H. Więckowska, Opozycja liberalna, s. 8.

${ }^{39}$ M. Mochnacki, Pisma krytyczne i polityczne, t. I, Kraków 1996, s. 87. W tym artykule Mochnacki krytykuje taką postawę, niemniej mimochodem przedstawia poglądy, jakie reprezentowali jego rywale polityczni. 
oka takie postępowanie w ferworze gwałtownych wydarzeń politycznych okazałoby się zrozumiałe. Jednak na podstawie analizy $O$ monarchii nie można się dopatrzyć żadnych tego symptomów. Tekst został przethumaczony rzetelnie. Chciałoby się, aby współczesne przekłady dokonywane były tak dokładnie.

$* * *$

Rozbiór tematu należy rozpocząć od analizy tych poglądów Wincentego Niemojewskiego, które były zbieżne z ideami promowanymi przez Benjamina Constanta.

Lider opozycji liberalnej postanowił opatrzyć tłumaczenie trzema wstępami. W pierwszym zostały zawarte refleksje dotyczące sytuacji polityczneje, połączone z uwagami natury metodologicznej dotyczącymi opracowanych prac Benjamina Constanta ${ }^{41}$. Następnie w tejże przedmowie w formie cytatów zawarto duży fragment mowy wstępnej francuskiego publicysty, który można odnaleźć w Réflexions sur les constitutions z 1814 roku $^{42}$, wreszcie przedmowa została zakończona krótkim fragmentem z De l'esprit de conquete ${ }^{43}$ o czym Niemojowski informuje ${ }^{44}$. Na koniec thumacz w pierwszym rozdziale pracy, który nazwał „Wstępem”45, umieścił rozważania $O$ udzielności ludu.

Przedmowę tłumacz rozpoczyna od wyjaśnienia, dlaczego konstytucja stanowi niezbędny element każdego prawidłowo funkcjonującego państwa. Konstytucja służy po nic innego - thumaczył Niemojowski - jak tylko po to, aby zagwarantować wolność. Tłumacz za wzór stawiał ustrój Anglii, gdzie miało panować „uszanowanie prawa dla człowieka i człowieka dla prawa”. Wolność nie podchodzi od narodu, ale jest prawem natury, które ma swoje źródło w Bogu ${ }^{46}$. We wstępie do Réflexions sur les constitutions Constant dodaje, ,że wolność polityczna, tak iest potrzebna Narodom, iak wolność cywilna" ${ }^{47}$. Społeczeństwo powstało więc, aby zapewnić jego mieszkańcom niezbędne prawa podstawowe.

Formą władzy gwarantującą wolność może być rząd republikański jak i monarchiczny, ograniczony „mądrą Konstytucyą i skombinowaną ze systemem reprezentacyynym"48 - czyli rząd monarchii reprezentacyjnej ${ }^{49}$. Teoria

40 O monarchii..., cz. I, s. 1-24.

41 Ibidem, s. 24-27.

42 Ibidem, s. 24-33; B. Constant, Réflexions sur les constitutions, la distribution des pouvoirs, et les garanties, dans une monarchie constitutionnelle, Paris 1814, s. v-xvi.

${ }^{43}$ Ibidem, s. 33-34; B. Constant, De l'esprit conquete et de l'usurpation, dans leurs rapports avec la civilisation Europenne, London 1814, s. 202-204.

44 O monarchii..., cz. I, s. 33.

45 Ibidem, s. 35-58.

46 Ibidem, s. 1-2.

47 Ibidem, s. 31.

48 Ibidem, s. 2.

49 Ibidem, s. 29. 
najlepszego ustroju w państwie została oparta na koncepcji przedstawionej przez Monteskiusza - „Rząd nayzdolniejszy iest [...] który naybardziey zgadza się ze stanem kraiu" ${ }^{\circ 0}$. Wincenty Niemojowski na podstawie analizy prac Arystotelesa zauważył jednak, że w praktyce, oprócz pierwotnych społeczeństw republikańskich, żadne „Towarzystwo” nie używało wolności i związanej z tym równości ${ }^{51}$. Tłumacz dowodził, że o ile w przypadku państw niewielkich i górzystych jak Szwajcaria, gdzie „przyrodzenie samo, zaprowadziło, do pewnego punktu, równość", rząd republikański jest najnaturalniejszy"52; o ile w Stanach Zjednoczonych, gdzie prawodawcy wzrośli z wieku oświecenia, a państwo nie było nigdy ograniczone władzą absolutną, możnym duchowieństwem i szlacheckimi przywilejami - przez co mogli ustanowić swoje instytucje na zasadach rozumu i wolności ${ }^{53}$. O tyle w większych państwach europejskich właściwy jest system monarchii konstytucyjnej ${ }^{54}$. W Europie ustrój republikański był wszak skompromitowany przez wydarzenia rewolucji francuskiej, w których republikę wprowadzano przez zbrodnie, nie mając podparcia w edukacji ani opinii doktrynerów republikańskich ${ }^{55}$.

Rząd monarchiczno-reprezentacyjny istnieje w zgodzie z moralnością, co uniemożliwia deprawację cnót monarchy ${ }^{56}$. Monarchia konstytucyjna, która zabezpieczy potęge króla ${ }^{57}$ i wolność poddanych, miała być rozwiązaniem problemu opisanego niegdyś przez Arystotelesa - degeneracji rządów. Za sprawą mądrej konstytucji, rządzący nigdy nie zamienią się w tyranów. Jak pisze Benjamin Constant, „Konstytucya nie iest czynem nieprzyiacielskim; iest czynem zgody"58.

Zbieżność postulatów zawartych w przedmowie thumacza oraz we wstępnych słowach Constanta była uderzająca. W przedmowie Niemojowskiego większy nacisk został położony na przytoczenie przykładów z innych pisarzy - głównie Monteskiusza, co miało na celu tym silniejsze utwierdzenie czytelnika w przekonaniu co do konieczności monarchii ograniczonej z respektowaną przez króla konstytucją.

Pochylę się nad „ostatnim wstępem”, noszącym tytuł O udzielności Ludu, który pierwotnie znajdował się w rozprawie - Principes de politique z 1815 roku, a bezpośrednio został zaczerpnięty z poprawionej wersji De la sou-

\footnotetext{
${ }^{50}$ Ibidem s. 2.

${ }^{51}$ Ibidem, s. 3-4.

52 Ibidem s. 7.

${ }^{53}$ Ibidem, s. 11.

54 Ibidem, s. 13. „Duch konstytucyyny, który w nich panuie (w państwach europejskich P. K.), nie iest duchemu republikańskim”.

55 Ibidem, s. 14. „Francya była więc Republiką, ale nie była republikańska”.

${ }^{56}$ Ibidem, s. 16-17.

${ }^{57}$ Ibidem, s. 29. Benjamin Constant pisze, że prerogatywy królewskie pozostają niezmiennie

58 Ibidem, s. 31.
} rozległe. 
veraineté du peuple z 1818 roku $^{59}$. Podobnie jak inne dzieła $\mathrm{z}$ tego okresu było to wydanie kolejnego elementu doktryny Constanta.

Nie bez powodu Niemojowski wstępny rozdział dzieła poświęcił udzielności ludu. Według Benjamina Constanta jest ona źródłem władzy zwierzchniej, natomiast władza niewzrastająca $z$ woli powszechnej musi być poparta siłą ${ }^{60}$. Udzielność ludu, innymi słowy: zasada suwerenności ludu, została zdefiniowana jako niezależna od formy rządów wyższość woli powszechnej nad wszelką wolą szczególną ${ }^{61}$.

Francuski publicysta za cel stawiał sobie rozprawienie się z niektórymi pomysłami swoich najgłośniejszych poprzedników. W tekście Constant przede wszystkim prowadzi polemikę z Rousseau, odnosi się też do idei Monteskiusza oraz Hobbesa. Jak uzasadniał, „rozumowaniem tylko, sprostować można rozumowanie" 62 . Z tej krytyki Benjamin Constant wyciaga wniosek, że istotą mechanizmu konstytucyjnego powinno być przestrzeganie „zasady wieczystej”, którą jest ograniczenie władz przez sprawiedliwość oraz przez prawa osobiste.

Nie istnieje taka suwerenność ludu, która nie jest ograniczona. Constant ma na myśli nie tylko zwierzchność ludu czy władcy, ale nawet zwierzchność prawa $^{63}$. I tak, sprawiedliwość powinna ograniczać udzielność, ponieważ wola ludu czy króla, a nawet Boga ${ }^{64}$ nie może czynić sprawiedliwym tego, co sprawiedliwe nie jest. Poszanowanie dla sprawiedliwości narzuca wszystkim pewność autorytetu ${ }^{65}$.

Ograniczenie udzielności możliwe jest zatem dzięki wartościom uznanym przez społeczeństwo, a promowanym przez opinię publiczną. Dopiero następnie może zostać umocniona przez podział i równowagę władz ${ }^{66}$. Stawiając tak wysoko opinię publiczna, Constant dawał zielone światło dla rozwoju prasy, która miała być tubą rozpowszechniającą wśród społeczeństwa ogólnie akceptowane wartości i cnoty.

Nie należy poprzestawać na samym ograniczaniu udzielności. Potrzeba poszukiwać takich podstaw dla instytucji publicznych, które by łączyły interes różnych ośrodków władzy. Jednakże naprzód trzeba oznaczyć ich podstawę i rozciagłość: „Jak ograniczyć inaczey władzę, ieśli nie przez władzę?”67. Po-

59 B. Constant, Cours de politique costitutionnelle au collecion des ouvrages publies sur le gouvernement representatif, t. I, Paris 1861, s. 272-284: idem, Collection complete des ouvrages publies, t. I, Paris 1818, s. 173-196.

${ }^{60}$ P. Bastid, Benjamin Constant, t. II, s. 867-868.

${ }^{61} \mathrm{O}$ monarchii..., cz. I, s. 35.

62 Ibidem, s. 55.

${ }^{63}$ Ibidem, s. 50.

64 Ibidem, s. 5: „Bóg sam, kiedy się miesza do rzeczy ludzkich, sprawiedliwość tylko potwierdza".

${ }^{65}$ P. Bastid, Benjamin Constant, t. II, s. 868.

${ }^{66}$ O monarchii..., cz. I, s. 52.

67 Ibidem, s. 51. 
szukiwane podstawy powinny wskazywać instytucjom publicznym ich interes w nieprzekraczaniu wyznaczonych konstytucyjnie prerogatyw. Nic dziwnego tedy, że doktrynę proponowaną przez Monteskiusza, opierającą się wyłącznie na dzieleniu władz i stawianiu ich w równowadze, autor nazywał „kombinacya dowcipną"68.

$$
\text { *** }
$$

Przedstawić wypada pokrótce akceptowane w całej rozciągłości przez tłumacza poglądy Benjamina Constanta dotyczące kształtu monarchii konstytucyjnej. Za najbardziej rozpoznawalny element doktryny uznaje się koncepcję pięcio-podziału władzy. „Władze konstytucyyne są następuiące: Władza Królewska, władza ministeryalna czyli wykonawcza, władza reprezentacyyna, czyli prawodawcza, władza sądowa, władza municypalna" ${ }^{9}$. Władza ustawodawcza znajduje się w prerogatywach zgromadzeń reprezentacyjnych, władza wykonawcza w rękach ministrów, a władza sądownicza należy do trybunałów. Król jest niejako pośrodku tych trzech władz.

„Monarchia konstytucyyna ma tę wielką korzyść, że stwarza ową władzę neutralną w osobie króla, iuż otoczoney tradycyami i pamiętkami; odzianey potęgą opinii, która iest podstawą wszelkiej polityczney potęgi" 70 . Le pouvoir neutre to arbiter rozstrzygający spory między innymi organami ${ }^{71}$. Organ miał sprawować arbitraż na dwóch płaszczyznach. Pierwszym obszarem były relacje między ministrami a parlamentem. Drugim zaś stosunki społeczno-polityczne. Instytucja została powołana z jednej strony, aby łagodzić konflikty między egzekutywą a legislatywą ${ }^{72}$, z drugiej zaś miała wyrastać ponad partykularne interesy poszczególnych grup i symbolizować harmonię i pluralizm panujący w społeczeństwie.

Constant enumeratywnie wymienia kompetencje władzy neutralnej w Réflexions sur les constitutions. Król nominuje i powołuje władzę wykonawczą ${ }^{73}$, ma prawo weta absolutnego ${ }^{74}$, prawo rozwiązania parlamentu oraz odroczenia jego sesji ${ }^{75}$, możliwość mianowania sędziów ${ }^{76}$, „Król ma prawo ułaskawienia"77, wreszcie władca decydował o wojnie i pokoju. Tak szeroko określone uprawnienia były niezbędne, aby monarcha mógł spełniać rolę organu zapew-

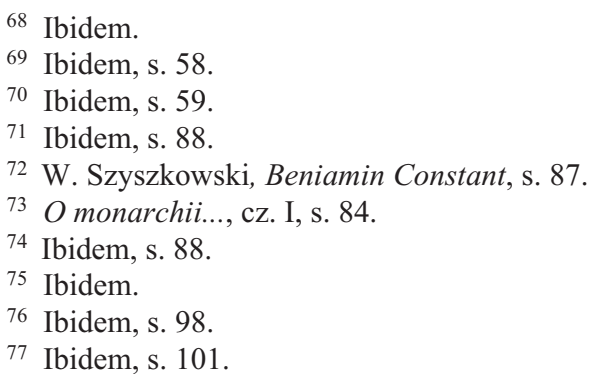


niającego sprawne funkcjonowanie całego systemu państwowego, ale też aby miał poczucie komfortu w nowej sytuacji politycznej.

Ministrowie mają być puklerzem władcy w kontaktach z ludem ${ }^{78}$. Król nigdy nie działa osobiście, ale przez swoich urzędników, dlatego naturalnym jest, aby to on miał prawo powoływać i zwalniać ministrów. Ministrowie obok posłów powinni mieć prawo inicjatywy ustawodawczej ${ }^{79}$. W ten sposób Constant wykluczył możliwość, aby ustawy mogły być wnoszone pod imieniem króla. Ministrowie mieli obowiązek kontrasygnowania wszystkich aktów władzy wykonawczej ${ }^{80}$.

Odpowiedzialność, wymieniona jako kolejna cecha ministrów, była dla całej konstrukcji instytucją kluczową. Wpierw autor rozróżnia odpowiedzialność polityczną od odpowiedzialności karnej, wobec której minister powinien podlegać na takich samych prawach jak zwykli obywatele ${ }^{81}$ : ,żaden czyn nieprawny, nie należy do urzędowania ministeryalnego, gdyż to urzędowanie, prawną tylko władzę nadaie" ${ }^{\prime 2}$. Urzędnik odpowiada przed królem w granicy upoważnienia prawnego, natomiast za czyny wykraczające poza to upoważnienie odpowiada jak za przestępstwo karne ${ }^{83}$. Benjamin Constant występował przeciwko nadaniu zgromadzeniu prawa pociagania ministrów do odpowiedzialności konstytucyjnej.

Władza reprezentacyjna powierzona została dwóm izbom. W systemie monokameralnym wszelkie środki ostrożności przeciw zbytniemu pośpiechowi takie, jak wielokrotne czytanie projektów albo konieczna większość bywają zawodne. Dlatego potrzebna jest druga izba, która stanowiąc przeciwwagę wobec pierwszej, będzie potrafiła bronić własnych interesów ${ }^{84}$.

Członkowie pierwszej izby dziedzicznej powinni być mianowani przez króla. Ich liczebność nie miała być w żaden sposób limitowana ${ }^{85}$. W monarchiach tradycyjnych „klasa dziedziczna” stanowiła podporę władcy i pośrednika w kontaktach z ludem. Bez niej rządy mogły mieć charakter jednie despotyczny ${ }^{86}$.

78 Ibidem, s. 112.

79 Uwagi do tego paragrafu pochodzą z notatki $F$ : De la proposition des lois au nom des ministres seuls. B. Constant, Collection complete des ouvrages publies, s. 225-231.

80 Uwagi do omawianego paragrafu pochodzą z notatki $G$ : Signature des actes du pouvoir ministériel par les ministres seuls. Ibidem, s. 231-234.

81 W. Szyszkowski, Benjamin Constant, s. 103. Autor monografii pierwszą odpowiedzialność nazywa parlamentarną, a drugą konstytucyjną. Nomenklatura wydaje mi się wyjątkowo niezręczna. Constant był zdecydowanym przeciwnikiem odpowiedzialności ministrów przed parlamentem.

82 O monarchii..., cz. I, s. 122.

83 Ibidem, s. 124.

84 Ibidem, s. 177-178. Benjamin Constant senat nazywał izbą pierwszą, a sejm określał mianem izby drugiej.

85 B. Constant, Collection complete des ouvrages publies, s. 239-242. W niniejszym paragrafie 2 został dołączony fragment notatki H: Hérédité de la pairie; ibidem, s. 234-245.

86 O monarchii..., cz. I, s. 178-179. 
Constant gwarancję widział w niewybieralności izby wyższej i jej nierozwiązywalności przez lud.

Wincenty Niemojowski w nocie sygnowanej na rok 1830 oświadczył, że zamierzał do paragrafu dodać swoje uwagi, ale ze względu na ówczesną dyskusję we Francji o kształcie parlamentu postanowił się wstrzymać z publikacją przypisu w pierwszym wydaniu. Oznajmił jednak, że nie podziela poglądu „szanownego autora” co do dziedziczności członków izby wyższej ${ }^{87}$.

„Druga izba iest obieralna bezpośrednio przez Lud" 88 . Autor przeciwstawiał się ówcześnie panującemu trendowi, który, tak jak to było w Ameryce, skłaniał się do wyborów poprzez elektorów. Tylko wybory bezpośrednie zgodne są z duchem wolności ${ }^{89}$. Izba niższa obok władzy wykonawczej ma prawo inicjatywy ustawodawczej ${ }^{90}$. Celem zgromadzeń jest przede wszystkim wyrażenie potrzeb obywateli ${ }^{91}$, a więc stanowi tubę przez którą mieszkańcy moga wyrażać swoje interesy. Prawodawcy powinni być liczni, gdyż ustawy mają być wypadkową wielu pomysłów. Podczas gdy władza wykonawcza widzi wyraźniej, co może szkodzić interesowi ogółu, o tyle władza ustawodawcza lepiej orientuje się w tym, co mogłoby być dobre dla kraju ${ }^{92}$. Za kształt każdego prawa władze odpowiadają przed opinią publiczną wspólnie i dlatego też obie powinny mieć prawo inicjatywy. Obrady sejmu jak i izby wyższej muszą odbywać się publicznie. Posłowie mogą być wybierani do parlamentu nieograniczoną liczbę razy ${ }^{93}$. Wybory do izby niższej odbywają się co 5 lat albo po rozwiązaniu jej przez króla ${ }^{94}$.

***

W pierwszej części thumaczenia zaprezentowano strukturę ustrojową monarchii konstytucyjnej. Władze zostały rozdzielone, prerogatywy udzielone, granice wytyczone. Ale to nie wszystko, aby nowe społeczeństwo konstytucyjne działało prawidłowo; oprócz należytego ułożenia rządu, wyznaczenia praworządnej ścieżki legislacyjnej potrzebni są odpowiednio przygotowani obywatele. W tym celu powinny zostać wyznaczone „rękojmie publiczne”. $Z$ jednej strony utrzyma to harmonię panującą między organami władzy, z drugiej pozwoli żyć ludziom w warunkach dla nich najwłaściwszych - opartych na poszanowaniu prawa, sprawiedliwości, współpracy, porządku, możliwości

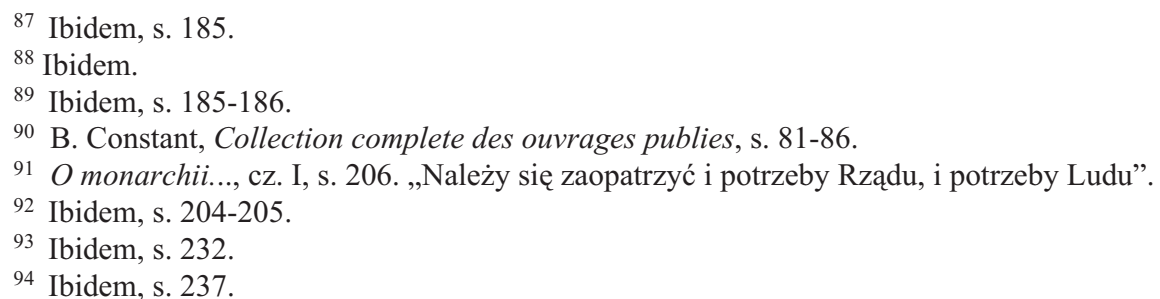


samorealizacji i rozwoju. Gwarancjami publicznymi - czyli wolnościami, których nie może naruszyć żadna władza - były prawa osobiste oraz prawa polityczne.

Constant uznał zasadę pełnej niezależności sędziów od egzekutywy za rękojmię sprawiedliwości. Władza sędziowska składa się z wybieranych dożywotnio przez władzę wykonawczą sędziów (juges) oraz sędziów przysięgłych (jurés). Sędziowie przysięgli powinni być losowani spośród obywateli używających prawa polityczne ${ }^{95}$. Urzędnicy charakteryzują się gorliwością, a w ich naturze leży wykonywanie rozkazów. Natomiast ,przysiężnika” cechować miały niezawisłość i bezstronność ${ }^{96}$.

Władzę sądowniczą wykonują tylko sądy. Tworzenie innych instytucji (np. komisji ${ }^{97}$ ) albo skracanie procedur sądowych trzeba uznać za czyn niekonstytucyjny $^{98}$. Sądy są gwarancją wolności, praworządności, uszanowania dla opinii publicznej, dlatego nie powinny być w żaden sposób omijane ${ }^{99}$.

Przez prawa polityczne autor rozumiał zdolność bycia powołanym do wszystkich urzędów publicznych, a także prawo głosu w wyborach posłów oraz urzędników, tj. bierne i czynne prawo wyborcze. Prawa wyborcze mieli mieć wszyscy obywatele, którzy posiadali własność gruntową lub przemysłową i opłacali podatki albo posiadali wieczystą lub długoletnią nieodwracalną dzierżawę, wystarczającą na ich utrzymywanie bez czyjejkolwiek pomo$\mathrm{cy}^{100}$. W uwagach Constant skupił się na pojęciu własności ${ }^{101}$. Własność wedle poglądu autora miała być wytworem społeczeństwa. Można sobie wyobrazić system polityczny bez własności, ale nie można przypuścić własności bez społeczeństwa. „Towarzystwo” uznało bowiem, że najlepiej będzie dla każdego używającego „dobra społeczne”, aby otrzymał ochronę prawną części tego dobra społecznego, które już posiada. Własność została więc nazwana „konwencyą towarzyską" (convention sociale), czyli innymi słowy: umową społecznąi ${ }^{102}$.

Wszyscy obywatele posiadają prawa osobiste niezależne od władzy politycznej ${ }^{103}$. Ludzie mają prawa osobiste, które nie mogą być zależne od

95 B. Constant, Collection complete des ouvrages publies, s. 251-258. Tłumacz przytacza notatkę I: De la nomination des jurés.

96 O monarchii..., cz. II, s. 2.

97 Constant miał przede wszystkim na myśli komisje wojskowe, który funkcjonowały w czasach rewolucji francuskiej.

98 B. Constant, Collection complete des ouvrages publies, s. 258-262. Thumacz przytacza fragment notatki K: Des tribunaux extraordinaires.

99 O monarchii..., cz. II, s. 55.

${ }^{100}$ Ibidem, s. 99.

${ }^{101}$ B. Constant, Collection complete des ouvrages publies, s. 292-295. Komentarz został zaczerpnięty z Notatki T: De la propriété.

102 O monarchii..., cz. II, s. 100.

${ }^{103}$ B. Constant, Collection complete des ouvrages publies, s. 300-317. Komentarz pochodzi z Notatki V: Des droits individuels. 
zwierzchności. Wolność osobista jest celem wszystkich umów społecznych. Bez niej nie ma ani pokoju, ani godności, ani szczęścia ${ }^{104}$. Samowolność (l'arbitraire) prowadzi do zguby moralnej, a bez moralności nie ma w państwie bezpieczeństwa.

Nareszcie należy wymienić wskazane przez Constanta prawa osobiste. Są to: wolność osobista, sąd przysiężniczy, wolność religijna, wolność przemysłowa, wolność własności, wolność druku.

Benjamin Constant w kwestii oddzielenia religii od państwa był prawdziwym radykałem. Postulował ustanowienie zupełnej wolności religijnej. Obywatele nie muszą ujawniać przed władzą własnych przekonań religijnych ${ }^{105}$.

Constant pod pojęciem wolności przemysłowej rozumiał tzw. „własny przemysł", czyli przyrodzone umiejętności, na przykład w przypadku robotnika miała tym być siła i zwinność własnych rąk. Stanął zdecydowanie na stanowisku obrony robotników przed, z zasady uprzywilejowanym, pracodawcą. Podstawowym prawem każdego powinno być prawo do pracy. Dlatego władza nie może nigdy decydować, kto do jakiej pracy jest zdatny; powinien o tym decydować pracodawca ${ }^{106}$.

Nie budzi wątpliwości, że należy zachować zupełną wolność druku z wyłączeniem jakiejkolwiek cenzury dla książek. Ułożenie książki wymaga bowiem czasu, nabycie ich - pieniędzy, a zrozumienie - odpowiedniego wykształcenia. Dlatego książki nie były przeznaczone dla każdego. Stąd wniosek, iż książki nie wywoływały zbytniego poruszenia i nie epatowały głów czytelników nazbyt rewolucyjnymi ideami. Inaczej się miała sytuacja z ,pisemkami ulotnymi”, czyli pamfletami i broszurami, a także z gazetami i dziennikami. Te były łatwiejsze do zrozumienia, prostsze do napisania i zdecydowanie tańsze - przez co znacznie dostępniejsze. Stąd wniosek francuskiego publicysty, że swoboda drukowania książek jest konieczna i zgodna z życzeniem ogółu.

Zdecydowanie bardziej kontrowersyjnie jawiła się sprawa czasopism i gazet. Przewaga gazet jest oczywista: zdecydowanie łatwiejszy do nich dostęp, a co za tym idzie, większa liczba czytelników. Benjamin Constant dostrzegł, że w jego czasach klasa oświecona mniej czyta, niż to było dawniej. Inteligencja nie poświęca się już zgłębianiu dzieł obszernych i wymagających czasu. Zajmuje się własnymi interesami albo oddaje się zabawie. Dla takich właśnie ludzi idealnym rozwiązaniem okazały się dzienniki, które stały się prawie jedyną ich lekturą ${ }^{107}$.

104 B. Constant, Collection complete des ouvrages publies, s. 317-327. Komentarz pochodzi z Notatki W: De la liberté personnelle.

${ }^{105} \mathrm{O}$ monarchii..., cz. II, s. 140.

106 B. Constant, Collection complete des ouvrages publies, s. 358-383. Komentarz pochodzi z Notatki Y: De la liberté d'industrie.

${ }^{107}$ O monarchii..., cz. II, s. 233. 
Większość postulatów Wincentego Niemojowskiego została wyłożona ustami Benjamina Constanta. Należałoby teraz te wywody uzupełnić. Pisanie o doktrynie autora powinno opierać się przede wszystkim na treści jego prac. W wypadku lidera kaliszan nie mamy takiego przywileju. Dlatego prócz informacji znalezionych w $O$ monarchii oparłem się przede wszystkim na wystapieniach thumacza na Sejmie Królestwa Polskiego, a także na jego działalności publicystycznej.

Głos posta kaliskiego ${ }^{108}$ był odpowiedzią na ocenzurowanie i wypaczenie wypowiedzi Niemojowskiego na sejmie w 1818 roku. Autor odżegnał się od informacji zawartych w Dyariuszu seymowym i postanowił własnym sumptem wydać uzupełnienie treści własnych przemówien. W przemówieniu w Izbie poselskiej z dnia 24 kwietnia Niemojowski najpełniej określa swoje postulaty. Celem lidera opozycji kaliskiej było nic więcej jak tylko nakłonienie ministrów do przestrzegania ustawy zasadniczej. Dlatego w mowach z 1818 roku ponad argumentacjami natury użyteczności danego przepisu stawiał zgodność projektów z ustawą zasadniczą. Pouczał posłów, że ci powinni przede wszystkim mieć na uwadze przestrzeganie konstytucji, potem dopiero kształt ustalonych praw.

Przy tej okazji przedstawię przypis tłumacza, dotyczący jawności obrad Sejmu, znaleziony w I części $O$ monarchii konstytucyyney. Z pewnością pomoże to lepiej zrozumieć sens publikowania Głosu posła kaliskiego. Pod pojęciem jawności obrad Niemojowski rozumiał jak najszersze poinformowanie obywateli o przebiegu obrad. Cel ten można było osiagnąć za sprawą publikowania diariuszy oraz za sprawą prasy. Według Statutu organicznego odpowiedzialnymi za ich sporządzanie byli sekretarze. Sekretarza Senatu mianował król, a sekretarza Izby poselskiej marszałek ${ }^{109}$. Dodatkowym artykułem do konstytucji z 13 lutego 1825 roku zniesiono jawność obrad Sejmu. Walka o protokół wpisywała się w ciąg poselskich utarczek z carem i jego urzędnikami o miejsce sejmu w systemie politycznym Królestwa Polskiego ${ }^{110}$.

Wincenty Niemojowski rozpoczął wywód od przedstawienia sytuacji we Francji, do której odnosił się Constant. W czasach Napoleona ciało prawodawcze nie miało prawa dyskusji nad projektami. Głosowania były tajne i odbywały się tylko po wysłuchaniu Rady Stanu i przedstawicieli Trybunatu. Nigdy jednak we Francji jawność obrad nie były kwestionowana ${ }^{111}$. „Trzeba szukać przyczyny tego w występkach. Usunięcia postępowania swego z pod wszelkie-

${ }^{108}$ W. Niemojowski, Głos posła kaliskiego na Seymie Królestwa Polskiego.

${ }^{109}$ Statut Organiczny Królestwa Polskiego, art. 85.

${ }^{110}$ M. Karpińska, ,Nie ma Mikołaja!” Starania o ksztalt sejmu w powstaniu listopadowym 1830-1831, Warszawa 2007, s. 14.

${ }^{111} \mathrm{O}$ monarchii..., cz. I, s. 210. 
go dozoru. Narzucenia się ludowi. Uiarzmienia go, przez iego niewiadomość"112.

Wincenty Niemojowski popierał postulat jawności obrad parlamentu. Po pierwsze, jeżeli rząd pretendował do bycia reprezentantem publicznym, wszystkie jego czyny powinny być jawne. Bez tego nie był rządem reprezentacyjnym, ponieważ niewiadome było czyje interesy popiera ${ }^{113}$. Dzięki jawności obrad publiczność poznaje powody i sens praw oraz wyroków. Prowadzi to do lepszego zrozumienia prawa, do szybszej akceptacji porządku, ale też pozwala lepiej zorientować się w działalności posłów. W ten sposób obserwatorzy, którzy mają przecież za pomocą wyborów wpływać na kształt parlamentu, stają się odpowiedzialni moralnie za ustanowione prawa ${ }^{114}$. Taki stan rzeczy oczyszcza atmosfere w opinii publicznej, albowiem znacznie trudniej podsycić niepewność obywateli nieprawdziwymi pomówieniami. Trudniej też posłom oszukać swoich wyborców co do przebiegu parlamentu i swoich na nim poczynań ${ }^{115}$.

„Przez iawność obrad seymowych; rozumie się naprzód wolny przystęp publiczności na posiedzenia seymowe". Liczba słuchaczy musiała zostać ograniczona. Zbyt wielkie audytorium uniemożliwia łatwość mówienia i słyszenia wypowiedzi. Jawność obrad nie ograniczała się tylko do grupy widzów znajdujących się na balkonach. Aby wszyscy obywatele mieli możliwość śledzenia obrad sejmu, potrzebne było ciagłe urzędowe publikowanie protokołów posiedzeń, a także bieżące informowanie przez niezależne gazety i dzienniki posiadające prawo relacjonować przebieg obrad. Niemojowski podkreślił, że publikacje powinny odbywać się w trakcie zwołanego sejmu, aby obywatele mogli wywierać świadomy wpływ na posłów ${ }^{116}$.

Protokoły urzędowe mające być czytane na każdym posiedzeniu izby powinny też zawierać: projekt inicjatywy ustawodawczej, słowa każdego uczestnika dyskusji, ostateczną treść uchwały, wynik głosowania uwzględniający liczbę oddanych głosów z imiennym wskazaniem każdego głosu. W ten sposób, oprócz wspomnianych wyżej zalet, wykształca się praktyka sejmowa, następne pokolenia posłów mają bowiem materiał, by uczyć się na błędach swoich poprzedników ${ }^{117}$.

W ten sposób opinia publiczna wybierałaby na posłów ludzi najbardziej oświeconych, najzdolniejszych i najmądrzejszy. Elekcja będzie pewniejsza w czasach spokojnych i dostatnich. Otwierało to możliwość dla ludzi, którzy mimo ogromnych zasług na polu myśli politycznej, nigdy nie mieli szans zasiąść w parlamencie.

\footnotetext{
112 Ibidem, s. 217.

113 Ibidem.

${ }^{114}$ Ibidem, s. 211.

115 Ibidem, s. 214.

116 Ibidem, s. 211-212.

${ }^{117}$ Ibidem, s. 211.
} 
Niemojowski odniósł się również do teorii Rousseau, jakoby lud nie powinien rządzić przez swoich reprezentantów, tylko osobiście. Autor przypisu odpowiada, że obecnie społeczeństwa są zbyt liczne, aby mogły działać skutecznie „same przez się”. Natomiast postulowaną przez Rousseau wolę powszechną i ogólny szacunek dla niej można osiąnnąc dzięki jawności obrad połączonej z wolnością druku. Postulowane zasady przywracają ludowi jego prawa pierwotne. Sprawiają że decyzje podejmowane na zgromadzeniach, na których rozstrzygany jest interes ogółu, mają charakter krajowy. W ten sposób Niemojowski znajduje nić porozumienia między poglądami Constanta oraz Jana Jakuba ${ }^{118}$.

Podobnie kształtuje się postulat jawności obrad rządu. Ujawniając swoje działania, ministrowie moga zaskarbić sobie sympatię publiczności i akceptację swych dalszych posunięć. Publikacja praw i środków administracyjnych jest najlepszą obroną przed pomówieniami ze strony opozycji i najlepszą gwarancją prawidłowo działającego rządu ${ }^{119}$.

Wincenty Niemojowski na Sejmie roku 1820 przy okazji dyskusji na temat kodeksu postępowania karnego postulował wprowadzenie sądów przysięgłych. Poseł kaliski w swoim przypisie zawartym na kartach $O$ monarchii konstytycyyney bezpośrednio nawiązał do tych wydarzeń, a w przypisie rozwinął swoją teorię na temat sądów przysięgłych ${ }^{120}$.

Poseł wieluński pisał: społeczeństwo działa na człowieka za pomocą prawa karnego, które popiera nałożone sankcje ${ }^{121}$. Jednak gdy wydawanie wyroków przekaże się władzy wykonawczej, wtedy szybko w państwa zapanuje tyrania i złamanie wolności, bo jak mówił Monteskiusz - wolność nie jest niczym innym jak bezpieczeństwem albo przynajmniej poczuciem bezpieczeństwa ${ }^{122}$. Społeczeństwo potrzebowało stworzyć instytucję odrębną od władzy wykonawczej, która zajmowałaby się wydawaniem wyroków. Powstanie władzy sądowniczej było więc następstwem nadużyć powodowanych w tym zakresie przez władzę ${ }^{123}$.

W każdym postępowaniu karnym muszą mieć miejsce dwa sądy: o czynie i o prawie. Bezpieczeństwo obywateli wymaga, aby obydwa wyroki nie pocho-

118 Ibidem, s. 215-216.

${ }^{119}$ Ibidem, s. 216.

${ }^{120}$ Ibidem, s. 45.

${ }^{121}$ Ibidem. Niemojowski przytacza cytat z Umowy społecznej: „Prawa kryminane, czyli karne, są zatwierdzeniem, sankcyą, wszystkich innych”. Tłumacz podaje źródło: J.J Rousseau, Umowa społeczna, II.11. W polskim wydaniu rozprawy Rousseau z 2002 r., w niniejszym rozdziale nie ma jednak o tym mowy. Może te świadczyć o omyłce Niemojowskiego.

${ }^{122}$ O monarchii.., cz. II, s. 12.

${ }^{123}$ Ibidem. 
dziły od tych samych ludzi ${ }^{124}$. W państwach, w których obywatele są równi wobec prawa, wydaje się logicznym, by co do winy decydowali współobywatele, którzy w przyszłości mogą znaleźć się w podobnie kłopotliwej sytuacji ${ }^{125}$. Wybór na sędziów przysięgłych nie powinien być trwały. Po jednorazowym osądzeniu wybrani mieli powrócić do zwykłych obowiązków ${ }^{126}$.

Sędziowie, którzy decyduja, jakie prawo zastosować, nie mogą być losowani spośród obywateli, ponieważ ich stanowisko wymaga posiadania specjalistycznego wykształcenia. Muszą być więc nominowani przez władzę wykonawczą stanowi to jednak wyłom w teorii podziału władz. Sposobem na osłabienie tego złego wpływu był postulat mianowania sędziów dożywotnio ${ }^{127}$.

Niezawisłość sędziów pozostaje zagrożona nawet w wypadku bycia powołanym dożywotnio. Po pierwsze, ze względu na to, że są wybierani przez władzę wykonawczą. Po drugie, rozwój kariery sądowej zależy od zwierzchników. Po trzecie, sędziowie mogą być poddawani presji zewnętrznej. Po czwarte, sędziowie profesjonalni ze względu na codzienną praktykę tracą wrażliwość społeczna, a wydawanie najsurowszych orzeczeń przychodzi im z niepokojąca łatwością ${ }^{128}$.

Jedną z największych zalet sądów przysięgłych było wzięcie pod uwage nie tylko przepisów prawa, ale też zasad etycznych. Sędziowie zawodowi skrępowani są przez liczne przepisy. Łatwo można wtedy oszukać sądy poprzez zastosowanie podstępnych kruczków prawnych. „Przysiężnicy” są znacznie bardziej wyrozumiali. Sprawy oskarżonych są im bliższe, kierują się, wreszcie, własnym sumieniem i zdrowym rozsądkiem ${ }^{129}$.

Co do zasad organizacji sądów przysięgłych Niemojowski w jednym miał inne zdanie niż Benjamin Constant. Chodziło mianowicie o ich skład. Francuski autor dopuszczał do sądów przysięgłych tylko obywateli posiadających prawa polityczne. Niemojowski był zaś przekonany o tym, że prawo zasiadania na ławie przysięgłych powinni mieć - w imię równości - wszyscy ci, którzy korzystają z praw obywatelskich. Jak się zaraz przekonamy, poseł kaliski nie okazał się tak postępowy, jakby się wydawało na pierwszy rzut oka.

Tłumacz przypomina, że sąd ,przysiężników” jest sądem równych. Dlatego nie powinno być grup uprzywilejowanych. Wyłączenie z losowania do sądów przysięgłych może wynikać jedynie z niezdolności lub na mocy zasady incompatibilitas.

Zdolność bycia „przysiężnikiem” powinna wynikać z posiadania praw obywatelskich oraz „, źwiatła dostarczanego ku ocenieniu czynu”. Praw oby-

\footnotetext{
${ }^{124}$ Ibidem, s. 13.

${ }^{125}$ Ibidem.

${ }^{126}$ Ibidem, s. 16-17.

${ }^{127}$ Ibidem, s. 14.

${ }^{128}$ Ibidem, s. 15-16.

${ }^{129}$ Ibidem, s. 35-36.
} 
watelskich nie posiadają osoby niepełnoletnie, a także ci, którzy prawomocnym wyrokiem zostali praw obywatelskich pozbawieni albo zostały im one zawieszone ${ }^{130}$. Co do zdolności umysłowych, należy ustanowić dwa domniemania. Odpowiednimi atrybutami rozumu dysponują posiadacze tytułów naukowych, uczestnicy „towarzystw uczonych” oraz wykonujący zawody: doktorów, adwokatów, notariuszy. Po drugie, osoby płacące wystarczająco wysokie podatki, które poświadczałyby ich sprawny umysł. Wielkość majątku dopuszczająca do brania udziału w sądach przysięgłych powinna być skalowana ze względu na wielkość miejsca zamieszkania. Ludzie wydający się bogaci na prowincji, w konfrontacji z mieszkańcami wielkich miast mogą okazać się ubodzy $^{131}$. Niniejsze wyłączenia zbliżają Niemojowskiego do generalnego poglądu Constanta, że odpowiedni majątek był najlepszym wyznacznikiem zdolności do wykonywania praw politycznych.

Inną grupą wyłączonych były osoby sprawujące niektóre funkcje publiczne. Nie można było łączyć roli przysięgłego z urzędami: senatora, posła, sędziego stałego, urzędnika publicznego, prokuratora, kapłana ${ }^{132}$.

Katalog osób uprawnionych do zasiadania w sądach przysięgłych na podstawie domniemania pierwszego pokrywał się w zasadzie z tym, jaki występował w rozdziałach VIII i IX Konstytucji Królestwa Polskiego. Drugie domniemanie rozszerza dostęp osób uprawnionych o mieszkańców prowincji, którzy ze względu na stosunkowo nikły majątek nie otrzymali praw politycznych. Jak sądzę, chodziło tu przede wszystkim o ubogą szlachtę, która pod rządami ostatnich konstytucji straciła prawa polityczne. Tak więc niniejszemu postulatowi przyświecał raczej zamysł polityczny niż chęć uczynienia doktryny Constanta bardziej postępową. Różnice poglądowe wynikały zatem z potrzeby lokalnej. Mimo wszystko wciąż szerokie wyłączenie większej części społeczeństwa pokazuje najdobitniej, jak Niemojowski i mu współcześni rozumieli pojęcie „równości”. Nie zmienia to faktu, że jeżeli zostanie przypomniane, iż prawa polityczne w Królestwie Polskim były udziałem znacznie większej części społeczeństwa niż we Francji, okazuje się, że ten punkt został zmieniony w sposób znaczny w stosunku do koncepcji Constanta.

Centralną rolę w rozważaniach Niemojowskiego pełni zasada wolności druku. Wolność druku ma zapewnić swobodę wymiany myśli, a co za tym idzie ukształtować opinię publiczną. Obywatele nie tylko będą mogli kontrolo- 
wać poczynania rządu, ale uczyć się popieranych przez ogół norm postępowania. Zatem uszlachetniać się i zaciskać więzi między sobą. W ten sposób społeczeństwo będzie funkcjonowało sprawniej i łatwiej będzie rozwiązywać napotkane przeszkody.

„Druk iest rodzaiem pisma, pismo iest wyobrażeniem mowy, mowa iest obrazem umysłu, a myśl, to iest sam człowiek. Cogito, ergo sum, powiedział Descartes"133. Wynika z tego, że skoro „myślę wolnie, więc iestem wolny [...] więc używam moiey wolności"134. Tym sposobem Niemojowski wskazywał wolność słowa jako niezbędny element bycia wolnym w ogóle. Wyrażanie swojej opinii jest tak naturalne jak poruszanie się. Stąd ewentualne obostrzenia powinny wyglądać tak samo jak w przypadku innych zwykłych czynności. Nie karze się przecież nikogo za poruszenie dłonią. Dlatego karać powinno się tak jak w kodeksie karnym: za czyny albo za usiłowanie czynu. Kary nie powinny obejmować samego użycia narzędzia druku ${ }^{135}$. Chodzi o wolność myślenia, od której zależy postęp cywilizacyjny „, i udoskonalenie przyrodzenia ludzkiego; [do którego - P.K.] przywiązany iest wszelki porządek polityczny, cywilny i moralny" $" 136$.

Wolność druku stanowi element umowy społecznej, która zastrzega dla społeczeństwa prawa do informacji o poczynaniach rządu i tego, co się w państwie dzieje. To obywatele swoimi daninami utrzymuja państwo, dlatego mają prawo wiedzieć, na co są przeznaczane ich pieniądze. „A cóż iest wolność druku? Jest kontrolą ustanowioną w Towarzystwie"137.

Opinia publiczna, a więc twór powstający w wyniku wolności druku, stanowi podporę i dla izby reprezentantów, i dla rządu. Bywa jednak często krytyczna wobec władzy - dlatego rządzący powinni uzbroić się w cierpliwość. Wsłuchując się w głos tłumu, rząd może znacznie lepiej poznać interes społeczny, jaki ma za zadanie reprezentować, ale też przy dozie samokrytycyzmu udoskonalić swoje funkcjonowanie. Nie ma bowiem nic gorszego niż zaślepienie, które pogłębia tylko oznaki „choroby” państwa ${ }^{138}$.

Kim jest główny przeciwnik wolności druku? Nie było nim państwo, nie powinien być neutralny król. Głównym antagonistą pozostają ministrowie oraz urzędnicy, na głowy których spada krytyka ze strony prasy. Uwagi dotyczą konkretnych urzędników, nie zaś urzędów in corpore. Przez gazety do przełożonych dochodzi opinia na ich temat, przez co aparat administracyjny nie pozostaje bezkarny w swoich decyzjach ${ }^{139}$ : „Ile razy, wolność druku, odkrywszy

\footnotetext{
${ }^{133}$ Ibidem, s. 267.

${ }^{134}$ Ibidem, s. 268.

135 Ibidem.

${ }^{136}$ Ibidem, s. 281.

137 Ibidem, s. 272.

${ }^{138}$ Ibidem, s. 269-270.

${ }^{139}$ Ibidem, s. 270.
} 
mnóstwo czynów arbitralnych, zabezpieczyła mieszkańców od swawoli lokalnych tyranów?"140.

Przestępstwa druku powinny być surowo karane, wyroki powinny wydawać sądy przysięgłe. Ocena szkodliwości publikowanych treści - aktu ludzkiego myślenia - wymyka się prawu i powinna być dokonana przez pryzmat sumienia sędziego, a nie zapisany artykuł w kodeksie ${ }^{141}$.

Drugim omawianym zagadnieniem w przypisie thumacza była kwestia cenzury. Kto krępuje wolność druku cenzurą, składa milczące wyznanie winy. Bez opinii publicznej władza nie zostaje oceniona. Opiera się tylko na własnej opinii na swój temat. Istnienie $\mathrm{w}$ gazetach tylko jednego państwowego prądu światopoglądowego prowadzić może jedynie do dalszej dezinformacji, przez co obywatele będą bardziej podatni na słodkie słowa propagandy ministrów ${ }^{142}$. Hamulcem również przytaczanym przez Constanta jest wierność cenzorów, którzy jak inni urzędnicy mogą otrzymać pieniężne premie tylko za gorliwe wykonywanie poleceń zwierzchników ${ }^{143}$.

Powyższe passusy to tylko poszlaki, na podstawie których została podjęta próba ułożenia mozaiki poglądów konstytucyjnych Wincentego Niemojowskiego. Czytając przytoczone fragmenty, można odnaleźć pewną regułę. Wszystkie przypisy zaczerpnięte z $O$ monarchii dotyczą wolności słowa. Zasada jawności oparta na publikacji diariuszy sejmowych i gazet ma na celu stworzenie określonej opinii publicznej. Rozdziały o wolności druku i zakazie cenzury są podporządkowane temu samemu celowi. Nawet zaprowadzenie sądów przysięgłych ma służyć lepszej ochronie wolności słowa przed sędziami pochodzącymi z nominacji. Niemojowski traktował wolność jako wartość nadrzędną, która powinna podlegać szczególnej gwarancji i ochronie ze strony państwa.

Pierwotnym zamiarem rozprawy była próba odtworzenia indywidualnych poglądów Wincentego Niemojowskiego. O ile zostało zaprezentowane jego myślenie o konstytucji, o tyle poszukiwanie pomysłów oryginalnych zakończyło się fiaskiem. Przyczyna nie leży jednak po stronie autora niniejszej rozprawy, ale po stronie Niemojowskiego. Zafascynowany poglądami Constanta stwierdził, że jak najdokładniejsze odwzorowanie tych koncepcji będzie znacznie cenniejsze niż podjęcie próby napisania własnej pracy. Czy tego rodzaju odtwórczość może być uznana za zarzut? W świetle tego, co założył sobie tłumacz - odpowiedź jest negatywna. Niemojowski był bowiem przede

\footnotetext{
140 Ibidem, s. 276.

${ }^{141}$ Ibidem, s. 279.

142 Ibidem, s. 288.

${ }^{143}$ Ibidem, s. 288-289.
} 
wszystkim politykiem albo, jak to pięknie napisała Helena Więckowska szermierzem wolności ${ }^{144}$. Może to określenie okazuje się nawet trafniejsze, ponieważ na każdym kroku działalności publicznej Niemojowskiego można dostrzec jego idealizm i upór.

Jak odnieść się do trafnej uwagi, że Benjamin Constant i Wincenty Niemojowski reprezentowali różne grupy interesu, gdyż pierwszy wywodził się z wielkiej burżuazji, drugi zaś popierał bogate ziemiaństwo? Czy w związku z tym nie może być mowy o pełnej recepcji doktryny Constanta? ${ }^{145}$. Na podstawie analizy tekstu okazuje się, że jedyna idea Niemojowskiego, która może odnosić się do ziemiaństwa w ogóle, to postulat nadania szerszej grupie ludzi uprawnień do zasiadania w sądach przysięgłych. Lider opozycji kaliskiej dostrzegał raczej lekarstwo w rozwiązaniu wielu problemów w unormowaniach ogólnych. Jeżeli wolności konstytucyjne zostaną zagwarantowane, umożliwi to harmonijny rozwój i dobrobyt wszystkich obywateli, w tym ziemiaństwa. Dlatego wydaje się, że także ten czynnik, który wpłynął na zmiany w treści tłumaczenia, został odparty przez Niemojowskiego na jego idealistycznej wierze w uniwersalność koncepcji Benjamina Constanta.

Przedstawione przez Niemojowskiego w przypisach poglądy mają za zadanie przede wszystkim ułatwienie zrozumienia zawiłej doktryny Constanta. Tłumacz pozostał bardzo oszczędny w komentarzach, nawet w swoich uwagach posługiwał się głównie cytatami innych autorów. Charakterystyczne było powtarzanie w przypisach tych samych idei. Niemojowski uzasadniał powtórzenia, pisząc: „Są prawdy, które potrzeba powtarzać aż do sytości, aby ie wyryć w umyśle ludzkim, i wpoić w tych, którym są użyteczne"146. Oprócz wielokrotnego powielenia identycznych argumentów i poglądów przypisy charakteryzuje łopatologiczny wywód, który czytelników bardziej doświadczonych może nawet znudzić. W ten sposób zdradzone zostaje, kto był adresatem tekstu: czytelnik nowy, którego zadaniem będzie w przyszłości działać na rzecz oświeconej opinii publicznej. Potrzeba nauczyć go nowych prądów, zachęcić do nich, tak aby w przyszłości był gotów świadomie walczyć o swoje prawa osobiste. W tym sensie grupa adresatów Niemojowskiego była znacznie szersza oraz bardziej otwarta niż ta Constanta, dlatego niezbędne okazały się dodatkowe „korepetycje”. Nie można się więc doszukać żadnych nowych pomysłów konstytucyjnych autorstwa Wincentego Niemojowskiego w O monarchii konstytucyyney, zresztą on sam hamował takie podejrzenia: „Nie pochlebiam sobie, abym iednę frazę wynalazł".

Poglądy promowane przez Wincentego Niemojowskiego nie znalazły naśladowców, a dzieło $O$ monarchii konstytucyyney zostało niemal całkowicie

${ }^{144}$ H. Więckowska, Przemiany myśli politycznej w Królestwie Kongresowym, s. 603.

${ }^{145} \mathrm{H}$. Izdebski, Instytucje przedstawicielskie w myśli politycznej Księstwa Warszawskiego i Królestwa Polskiego, s. 38.

${ }^{146} \mathrm{O}$ monarchii..., cz. II, s. 267. 
zapomniane. Okresem kluczowym, charakteryzującym się szczególnie bujnym rozwojem myśli politycznej, był czas wielkiej emigracji ${ }^{147}$. Niemojowscy nie wywarli wówczas żadnego wpływu. Wincenty nigdy do Paryża nie dotarł, natomiast Bonawentura zmarł już w 1835 roku. Doba powstania listopadowego nie sprzyjała dalekosiężnym programom ukształtowania wolnej Polski ${ }^{148}$. Wreszcie, przyjęło się cenić pomysły oryginalne i nowe, nie zaś thumaczenia prac, jak pisał Monteskiusz: kto zawsze tłumaczy, tego dzieła nigdy nie będą thumaczone.

\section{Wykaz źródel i opracowań}

\section{Źródla drukowane}

Constant Benjamin, Collection complete des ouvrages publies sur le Gouvernement representatif et la Constitution actuelle de la France, formant une espece de Cours de Politique constitutionnelle, t. I-II, Paris 1818

- Cours de politique costitutionnelle, t. I-II, Paris 1836

- Cours de politique costitutionnelle au collecion des ouvrages publies sur le gouvernement representatif, t. I, Paris 1861

- De l'esprit conquete et de l'usurpation, dans leurs rapports acec la civilisation Europeenne, London 1814

- Dzienniki poufne, przeł. Joanna Guze, Warszawa 1980

- O monarchii konstytucyyney i rekoymiach publicznych. Rzecz wzięta z dzieł Benjamina Constant przektadnia Wincentego Niemojowskiego, t. I-II, Warszawa 1831

- Principes de politique, applicables a tous les gouvernemens representatifs et particulienement a la constitution actuelle del la France, Paris 1815

- Refléxions sur les constitutions, la distribution des pouvoirs, et les garanties, dans une monarchie constitutionnelle, Paris 1814

- Zasady polityki majace zastosowanie do wszystkich rzadów (wersja z lat 1806-1810), przeł. Anastazja Dwulit, Warszawa 2008

Dziennik posiedzeń izby poselskiej w czasie sejmu Królestwa Polskiego w roku 1820, Warszawa 1820

Lelewel Joachim, Materiaty autobiograficzne, oprac. Helena Więckowska, Warszawa 1957

Mochnacki Maurycy, Pisma krytyczne i polityczne, t. I, Kraków 1996

- Powstanie narodu polskiego w roku 1830 i 1831, t. I-II, Warszawa 1984

Montesquieu Charles, O duchu praw, t. I-II, przeł. Tadeusz Boy-Żeleński, Warszawa 1957

Niemojowski Jan Nepomucen, Wspomnienia, Warszawa 1925

Niemojowski Wincenty, Głos posła kaliskiego na sejmie Królestwa Polskiego 1818, Poznań 1818

- Myśli dorywcze o romantyczności i romantykach, Kalisz 1830

- O Wtadzach publicznych. W Monarchii Konstytucyyney wedtug B.C. przez W. N., „Pamiętnik Warszawski”, XXI, 1821

— Przemówienie sejmowe na XVI sesji Izby Poselskiej w dniu 24 IV 1818 r., [w:] Dyaryusz Seymu Królestwa Polskiego 1818, t. III, Warszawa 1818

Rousseau Jean Jacques, Umowa społeczna, przeł. Antoni Peretiatkowicz, Kęty 2002

${ }^{147}$ L. Trzeciakowski, Wplyw powstania listopadowego na polska myśl politycznq XIX wieku, [w:] Powstanie listopadowe a problem świadomości historycznej, pod red. L. Trzeciakowskiego, Poznań 1983, s. 59.

148 Ibidem, s. 60. 
Zwierkowski Walenty, Rys powstania, walki i działań Polaków 1830 i 1831 roku skreślony w dziesięć lat po wypadkach na tułactwie we Francji, wyd. W. Lewandowski, Warszawa 1973

\section{Prasa}

„Dekada Polska” 1821

„Gazeta Codzienna, Narodowa i Obca” 1818-1819

„Kronika drugiej połowy r. 1819”

„Kurier Polski” 1830-1831

„Orzeł Biały” 1819-1820

„Pamiętnik Warszawski czyli Dziennik nauk i umiejętności” 1815-1821

\section{Opracowania}

Ajnenkiel Andrzej, Historia Sejmu Polskiego, t. II cz. I, Warszawa 1989

Baczko Bronisław, Rousseau: samotność $i$ wspólnota, Warszawa 1964

Barszczewska-Krupka Alicja, Generacja powstańcza 1830-1831, Łódź 1985

Bastid Paul, Benjamin Constant et sa doctrine, t. I-II, Paris 1966

Baszkiewicz Jan, Wolność, Równość, Własność: rewolucje burżuazyjne, Warszawa 1981

Bernacki Włodzimierz, Liberalizm polski 1815-1939: studium doktryny politycznej, Kraków 2004

- O własności w nurtach liberalizmu polskiego w XIX w., „Czasopismo Prawno-Historyczne”, LVI, 2004, z. 1, s. 223-230

- Wolność w dobie zaborów i w II RP - idea i polityka, [w:] Wolność i jej granice. Polskie dylematy, pod red. Jacka Kloczkowskiego, Kraków 2007, s. 79-105

Bończa-Tomaszewski Nikodem, Narodziny polskiego liberalizmu - analiza metod wyjaśniania historiografii polskiego liberalizmu, „Kwartalnik Historyczny”, t. CVIII, 2001, s. 83-98

Bortnowski Władysław, Kaliszanie. Kartki z dziejów Królestwa Polskiego, Warszawa 1976

- Udziat „kaliszan” we władzach powstania listopadowego, [w:] Osiemnaście wieków Kalisza, t. III, pod red. A. Gieysztora, Kalisz 1962, s. 227-267

- Walka o cele powstania listopadowego (od 29 listopada 1830 r. do lutego 1831 r.), Wrocław 1960

Bosiacki Adam, Władza municypalna w ujęciu Benjamina Constanta a teorie podziału władzy, „Studia Iuridica" IIL, 2008, s. 341-347

Bożek Michał, Koncepcja władzy neutralnej Benjamina Constanta, [w:] Idee jako źródło instytucji politycznych i prawnych, red. Lech Dubel, Lublin 2003, s. 405-425

- Znaczenie koncepcji władzy neutralnej Benjamina Constanta we wspótczesnym konstytucjonalizmie, [w:] Konstytucjonalizm a doktryny polityczne. Najnowsze kierunki badań, red. R.M. Małajny, Katowice 2008, s. 167-172

Braunsteinówna Helena, Charakterystyka braci Niemojowskich ( $w$ dobie Królestwa Kongresowego), „Przegląd Historyczny” XXIII, 1922, s. 61-85

Chojnicka Krystyna, Olszewski Henryk, Historia doktryn politycznych i prawnych, Poznań 2004

Deslandres Maurice, Historie constitutionnelle de la France de 1789 à 1870, t. I-II, Paris 1932

Dubel Lech, Historia doktryn politycznych i prawnych do końca XIX wieku, Warszawa 2002

Dutkiewicz Józef, 1830-1831 - powstanie czy rewolucja? Na podstawie analizy Diariusza Sejmu, [w:] Powstanie czy rewolucja: w 150. rocznice Powstania Listopadowego, pod red. Henryka Kocója, Katowice 1981, s. 17-26

Feldman Wilhelm, Dzieje polskiej myśli politycznej. (Próba zarysu), t. I, Warszawa 1988

Gąsiorowska Natalia, Wolność druku w Królestwie Kongresowym 1815-1830, Warszawa 1916

Gołba Zdzisław, Rozwój władz Królestwa Polskiego w okresie Powstania Listopadowego, Wrocław-Warszawa-Kraków-Gdańsk 1971

Grzybowski Konstanty, Dwa nurty polskiej myśli konstytucyjnej, „Kwartalnik Historyczny” LIX, 1952, s. 45-60

Handelsman Marceli, Francja-Polska 1795-1845: studia nad dziejami myśli politycznej. Rozwój narodowości nowoczesnej, t. II, Warszawa 1926 
- Les idees francaises et la mentalite politique en Pologne au XIX siecle, Paris 1927

Izdebski Hubert, Instytucje przedstawicielskie w myśli politycznej Księstwa Warszawskiego i Królestwa Polskiego (do 1831 roku), [w:] Polska myśl liberalno-demokratyczna w latach 1795-1830, Warszawa 1986, s. 21-50

- Ustawa konstytucja Królestwa Polskiego 1815, [w:] Konstytucje polskie: studia monograficzne $z$ dziejów polskiego konstytucjonalizmu, pod red. Mariana Kallasa, Warszawa 1990, s. 217-219

Janowski Maciej, Polska myśl liberalna do roku 1918, Kraków 1998

- O historię liberalizmu polskiego w XIX wieku (W odpowiedzi na artykut Nikodema Bończy-Tomaszewskiego), „Kwartalnik Historyczny”, CIX 2002, s. 101-117

Kalembka Sławomir, Manifesty polityczne i programy ideowe w ideologiach europejsko-polskich, próba porównania, [w:] Polskie powstania narodowe na tle przemian europejskich w XIX wie$k u$, pod red. Anny Barańskiej, Witolda Matwiejczyka, Jana Ziółka, Lublin 2001, s. 99-112

Karpińska Małgorzata, „Nie ma Mikołaja!” Starania o ksztalt sejmu w postaniu listopadowym 1830-1831, Warszawa 2007

Kizwalter Tomasz, Między Konstytucja 3 Maja, a Noca Listopadowa: dzieje państwowości, przemiany społeczne, ewolucja polskiej myśli politycznej, [w:] Polska myśl liberalno-demokratyczna w latach 1795-1830, Warszawa 1986, s. 10-20

Kruszyńska Sabina, Benjamin Constant. Filozof religii: religia-moralność-wolność, Gdańsk 2000

Ludwikowski Rett Ryszard, Główne nurty myśli liberalnej 1815-90, Warszawa 1982

- Sukces czy porażka, „Czasopismo Prawno-Historyczne”, t. XXX, 1978, z. 1, s. 175-180

Łagowski Bronisław, Filozofia polityczna Maurycego Mochnackiego, Kraków 1981

Łojek Jerzy, Opinia publiczna a geneza Powstania Listopadowego, Warszawa 1982

- Studia nad prasa i opinia publiczna w Królestwie Polskim 1815-1830, Warszawa 1996

Manent Pierre, Intelektualna historia liberalizmu, tł. Marian Miszalski, Kraków 1994

Mycielski Maciej, „,Miasto mieszkańców, wieś obywateli”. Kajetana Koźmiana koncepcje wspólnoty politycznej (do 1830 roku), Wrocław 2004

Przelaskowski Ryszard, Sejm warszawski roku 1825, Warszawa 1929

Pusz Wiesław, Wokół periodyków Brunona Kicińskiego „,Orzeł Biaty” i sejmiki uzupetniajace skład postów (styczeń-luty 1820), [w:] „Wiek Oświecenia”, t. XIII

Rau Zbigniew, Jakich obywateli potrzebuje państwo liberalne?, [w:] Cnoty polityczne - dawniej i obecnie, pod red. Romualda Piekarskiego, Gdańsk 1997, s. 333-343

- Liberalizm: zarys myśli politycznej XIX i XX wieku, Warszawa 2000

- Zapomniana wolność: w poszukiwaniu historycznych podstawa liberalizmu, przeł. Marek Przychodzeń, Warszawa 2008

Rembowski Aleksander, Nasze poglady polityczne w roku 1818. (Konstytucja, monarchizm, Sejm, opozycja), [w:] idem, Pisma, t. I, Warszawa 1901, s. 69-143

Rostocki Władysław, Elementy postepowe w ideologii politycznej $i$ w ustroju powstania listopadowego, „Czasopismo Prawno-Historyczne” VII, 1955, s. 163-200

Skarżyński Ryszard, Czy liberalizm byt w Polsce w ogóle możliwy?, [w:] Tradycje liberalne w Polsce, Warszawa 1993, s. 15-26

Skowronek Jerzy, Skład społeczny i polityczny sejmów Księstwa Warszawskiego i Królestwa Polskiego, „Przegląd Historyczny” LII, 1961, s. 474-491

Słomkowska Alina, Dziennikarze Warszawscy: szkice z XIX wieku, Warszawa 1974

Sobolewska Barbara, Sobolewski Marek, Myśl polityczna XIX i XX w. Liberalizm, Warszawa 1978

- Doktryna polityczna liberalizmu arystokratycznego we Francji w latach 1815-1848, Kraków 1977

Stankiewicz Zbigniew, Sejm Królestwa Polskiego, „Czasopismo Prawno-Historyczne”, XXXVI, 1984, z. 1, s. 105-142.

Szyszkowski Wacław, Beniamin Constant: Doktryna polityczno-prawna na tle epoki, Warszawa 1984

Więckowska Helena, Opozycja liberalna w Królestwie Kongresowym 1815-1830, Warszawa 1925

- Przemiany myśli politycznej w Królestwie Kongresowym, [w:] Pamiętnik V Powszechnego Zjazdu Historyków Polskich w Warszawie, 28 listopada do 4 grudnia 1930 r., pod red. Kazimierza Tyczkowskiego, Lwów 1930, s. 598-612 
Zajewski Władysław, Niemojowski Bonawentura, w: Polski słownik biograficzny, XXIII, 1978, s. $22-27$

- Niemojowski Wincenty, w: Polski stownik biograficzny, XXIII, 1978, s. 31-34

- Kaliszanie, [w:] Tradycje liberalne w Polsce: sympozjum historyczne, oprac. i przygot. Roman Benedykciuk, Ryszard Kołodziejczyk, Warszawa 2004, s. 83-96

- Kaliszanie. Rodowód polskiego liberalizmu, [w:] Studia z dziejów polskiej myśli politycznej IV. Od reformy państwa szlacheckiego do myśli o nowoczesnym państwie, Toruń 1992, s. 89-105

- Wolność druku w okresie władzy Rzadu Narodowego w 1831 „Czasopismo Prawno-Historyczne" XIII, 1963, z. 2, s. 159-194

-, Dutkiewicz Józef, O niektórych aspektach postępowego nurtu ideologicznego w Powstaniu Listopadowym, „Czasopismo Prawno-Historyczne” IX, 1957, z. 1, s. 283-311 